\title{
Assessment of freshwater ecosystem services in the Beas River Basin, Himalayas region, India
}

\author{
Sikhululekile Ncube, Lindsay Beevers, Adebayo J. Adeloye, and Annie Visser \\ Institute for Infrastructure and Environment, School of Energy, GeoScience, \\ Infrastructure and Society, Heriot-Watt University, Edinburgh, EH14 4AS, UK
}

Correspondence: Sikhululekile Ncube (s.ncube@hw.ac.uk, snmancue@gmail.com)

Received: 30 December 2017 - Revised: 4 April 2018 - Accepted: 5 April 2018 - Published: 5 June 2018

\begin{abstract}
River systems provide a diverse range of ecosystem services, examples include: flood regulation (regulating), fish (provisioning), nutrient cycling (supporting) and recreation (cultural). Developing water resources through the construction of dams (hydropower or irrigation) can enhance the delivery of provisioning ecosystem services. However, these hydrologic alterations result in reductions in less tangible regulating, cultural and supporting ecosystem services. This study seeks to understand how multiple impoundments, abstractions and transfers within the upper Beas River Basin, Western Himalayas, India, are affecting the delivery of supporting ecosystem services. Whilst approaches for assessing supporting ecosystem services are under development, the immediate aim of this paper is to set out a framework for their quantification, using the macroinvertebrate index Lotic-Invertebrate Index for Flow Evaluation (LIFE). LIFE is a weighted measure of the flow velocity preferences of the macroinvertebrate community. Flow records from multiple gauging stations within the basin were used to investigate flow variability at seasonal, inter-annual and decadal time scales. The findings show that both mean monthly and seasonal cumulative flows have decreased over time in the Beas River Basin. A positive hydroecological relationship between LIFE and flow was also identified, indicative of macroinvertebrate response to seasonal changes in the flow regime. For example, high LIFE scores (7.7-9.3) in the winter and summer seasons indicate an abundance of macroinvertebrates with a preference for high flows; this represents a high potential for instream supporting ecosystem services delivery. However, further analysis is required to understand these hydroecological interactions in the study basin and the impact on instream supporting ecosystem services delivery.
\end{abstract}

\section{Introduction}

River systems provide an array of ecosystem services, ranging from tangible benefits such as freshwater supply (provisioning) to the less tangible where examples include religious enrichment (cultural), climate regulation (regulating) and nutrient cycling (supporting) (Gilvear et al., 2017). Some riverine ecosystem services may be enhanced through the development of water resources such as the construction of dams for hydropower and/or irrigation to meet prioritised human needs. However, there are often trade-offs between the ecosystem service categories, with downstream ecosystems and the ecosystem services they provide, paying the price (Millennium Ecosystem Assessment, 2005). More often, such trade-offs result from developments which increase the delivery of provisioning ecosystem services, but negatively impact less tangible cultural, regulating and supporting ecosystem services.

In river basins such as the Beas, Western Himalayas, India, increasing water demands for domestic, industrial and irrigation purposes and hydropower generation have led to rapid development. Additionally, changing climatic conditions have led to increases in temperature, decreased snow fall and glacier shrinkage (Jain et al., 2010). These drivers of change have, and continue, to impact on the delivery of ecosystem services, particularly those which are less tangible.

Supporting ecosystem services underpin the delivery of all other ecosystem services. Therefore, to recognise the im- 


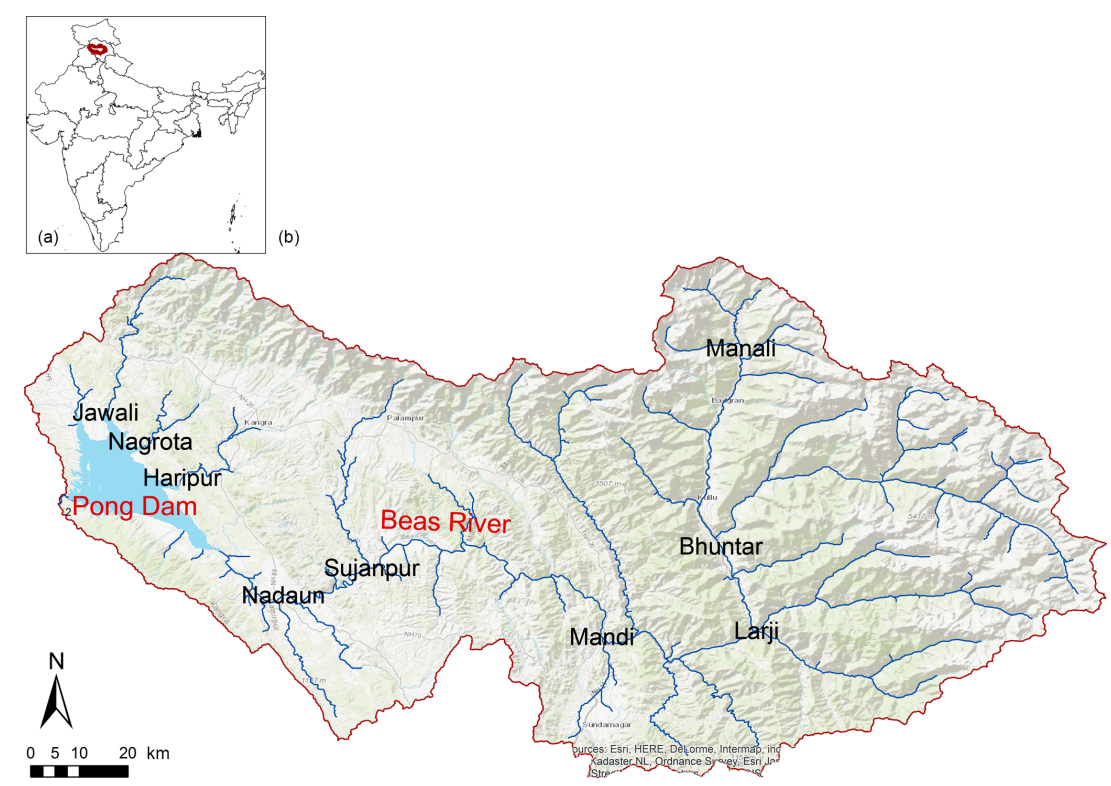

Figure 1. Map of the Beas River Basin and its situation (inset).

pact of developments on ecosystem service delivery, process understanding of the formation and regulation of these supporting ecosystem services is essential. Due to their sensitivity to change (Chaube et al., 2008; Chauhan and Verma, 2016), macroinvertebrates have widely been used as ecological indicators of the impact of flow regulation and abstraction in river systems (Ghosh and Biswas, 2015; Monk et al., 2008). Macroinvertebrates play a significant role in the delivery of supporting ecosystem services in river systems (Thorp et al., 2010). As primary consumers, detritivores, predators and pollinators, macroinvertebrates contribute to supporting ecosystem services such as nutrient cycles, primary productivity, and decomposition. Additionally, in freshwaters, macroinvertebrates operate at intermediate trophic levels (approximately the middle of the food web) and are generally the main in-stream food source of fish (Wallace and Webster, 1996).

To assess the ecological response of macroinvertebrates to flow regime the Lotic-invertebrate Index for Flow Evaluation (LIFE) (Extence et al., 1999) is commonly used (Monk et al., 2006). LIFE is abundance-weighted, based on macroinvertebrate flow velocity preferences. Knowledge on the applicability of LIFE on snow fed river systems, such as the Beas River, is limited. The results presented in this paper are part of ongoing work. The overall aim of this study is to understand the impact of the altered flow regime on supporting ecosystem services delivery potential in the case study basin, using macroinvertebrates as an indicator.

\section{Materials and Methods}

\subsection{Study Area}

The source of the Beas River is located in the Himalayas, central Himachal Pradesh, India; the river merges with the Satluj River at Harike in Punjab. The Beas River is one of the main tributaries of the Indus River system, which is critical for food, energy and economic development in India. Figure 1 shows the location of the Beas River Basin in North India. The Pong Dam reservoir is situated downstream in the basin; the dam is mainly used for hydropower generation and irrigation water supply.

\subsection{Daily stream flow discharge data}

Historic daily mean stream flow discharge data for the study area was made available by the Bhakra Beas Management Board (BBMB) for two gauging stations: Nadaun (from 1980 to 2017) and Thalout (from 1967 to 2007) (Fig. 2).

Time varying seasonal and decadal summary flow statistics were calculated to understand the long-term flow variability which may influence macroinvertebrates, and hence, the provision of supporting ecosystem services. These included mean monthly flows, the cumulative seasonal flow exceeded $10 \%$ of the time $\left(Q_{10}\right)$ and the cumulative seasonal flow exceeded $90 \%$ of the time $\left(Q_{90}\right)$. While $Q_{10}$ is a measure of high flows, the $Q_{90}$ is a measure of low flow. Seasons were defined as the following hydrological periods: Summer (pre monsoon) (March-May), Monsoon (June-September), Autumn (Post monsoon) (October-November) and Winter (December-February). 


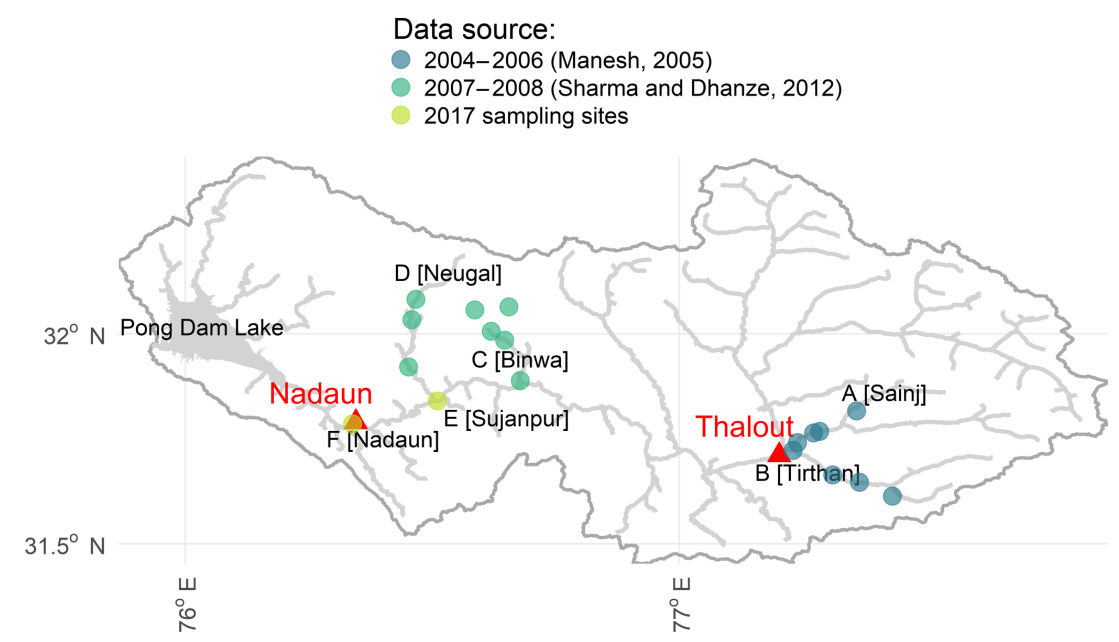

Figure 2. Historic and recent (2017) sampling sites in the Beas River Basin. Sampling reaches are labelled A to F.

\subsection{Macroinvertebrate data}

The macroinvertebrate sampling locations (historic and from 2017) are detailed in Fig. 2. The historic sampling sites are located on the tributaries of the Beas River whilst the 2017 sampling sites are located on the main stem.

\subsubsection{Historic macroinvertebrate data}

Two previous studies were used as sources of historic macroinvertebrate data. Historic macroinvertebrate data, sampled monthly, was made available from: Manesh (2005) in 2005-2006 at A and B (Fig. 2, Sainj River and Tirthan River) and Sharma and Dhanze (2012) in 2007-2008 at C and D (Fig. 2; Binwa River and Neugal River). Data from these historic studies was used to calculate seasonal LIFE scores. This seasonality was considered with reference to seasonal changes in the Beas River flow regime.

\subsubsection{Current macroinvertebrate sampling}

Additional macroinvertebrate sampling was carried out as part of this study at E and F (Fig. 2; Sujanpur and Nadaun on the main stem). Sampling was carried out during the post-monsoon period in November 2017. The kick-sampling method (Barbour et al., 1999) was used to collect the macroinvertebrates from both sampling sites. A handnet ( $1 \mathrm{~mm}$ mesh size) was used to collect two samples at each site to form a single composite sample per site. Kick-sampling required disturbing the river bed for a duration of 3 min whilst the handnet is held vertically to the river bed, with the frame of the net at right angles to river flow (downstream of one's feet). Dislodged macroinvertebrates within an area close to the net were gathered and subsequently stored in containers and preserved with $90 \%$ ethanol for identification in the laboratory. The samples were sorted and taxonomically identified to Family level following Subramanian and Sivaramakr- ishnan (2007). Family LIFE scores were calculated via the method described by Extence et al. (1999) (refer to Supplement 1).

\section{Results and Discussion}

\subsection{Flow variation over time}

Figure 3 depicts the decomposed time series of the mean monthly flows at both gauging stations. There are strong similarities in flow seasonality, with high flows during the monsoon season and low flows during the winter season. Overall, the mean monthly flows show a decreasing trend after the 1990s. The observed facet (Fig. 3) also shows trend change points in the 1990s, thereafter the flows appear to decrease.

Mean monthly flows from Nadaun gauging station are more variable compared to Thalout upstream; this is also reflected by irregularities in flows at Nadaun during the change point in the 1990s.

Similarly, analysis of seasonal cumulative flows shows a shift over time in both the $Q_{90}$ and $Q_{10}$ as revealed in Fig. 4.

As illustrated in Fig. 4, both gauging stations depict similar trends of decreasing cumulative flows over the four seasons, especially the monsoon flows. The Nadaun station recorded a noticeable decrease in $Q_{10}$ and $Q_{90}$ monsoon flows from the 1980s to 2017. On the other hand, the Thalout station shows a noticeable downward shift in $Q_{10}$ and $Q_{90}$ during the winter season from the 1960s to the 2000s.

These decreases in both mean monthly flows and seasonal cumulative flows in the Beas River could be the result of climatic change and human activity impacts linked to increases in abstraction activities and hydropower generation in the basin (Singhvi and Krishnan, 2014).

\subsection{LIFE scores}

Figure 5 provides a comparison of the LIFE scores. 


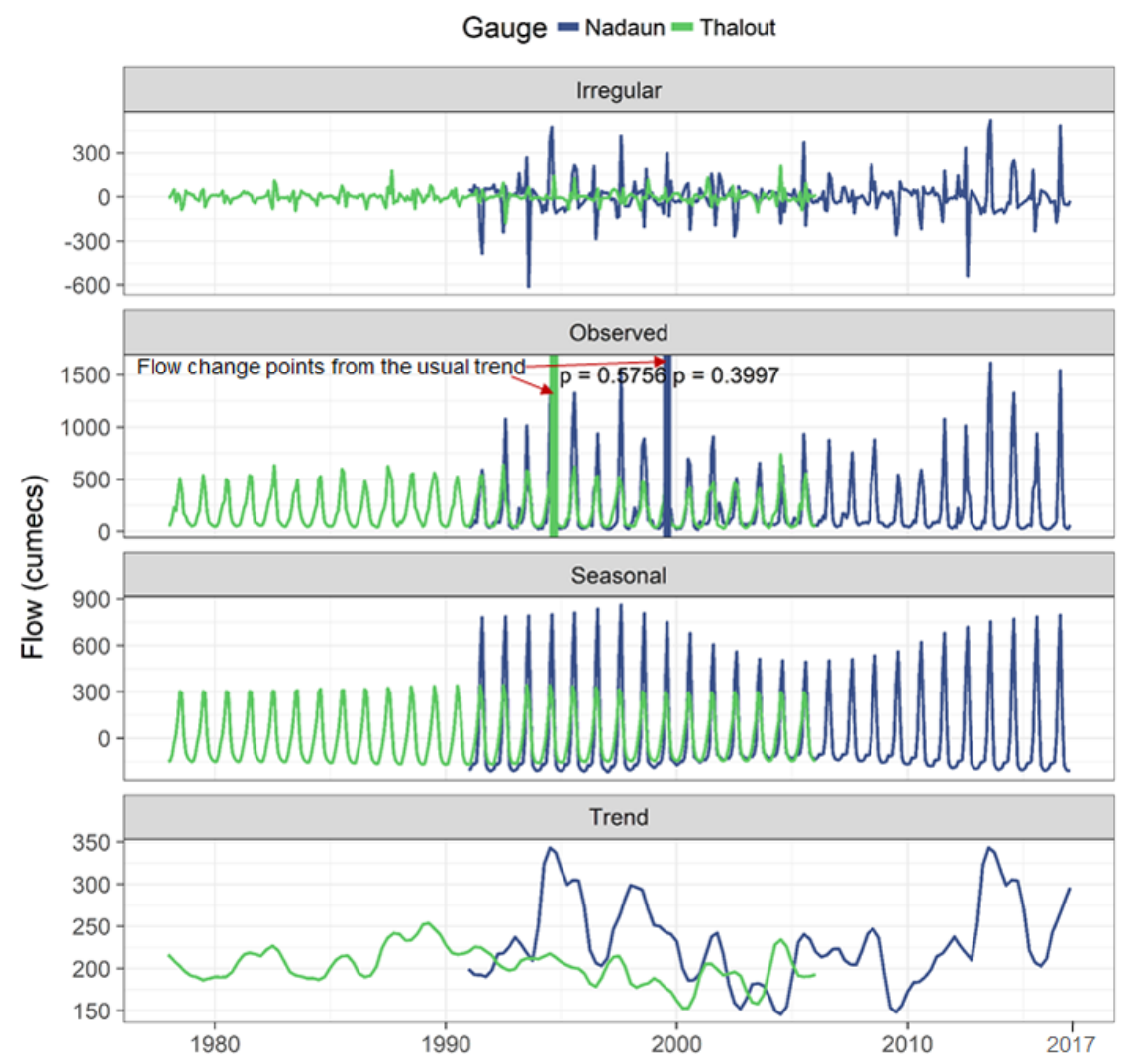

Figure 3. Decomposed time series of mean monthly flows at the two gauging stations.

Despite differences in the spatial location and timing of sampling, similar patterns in macroinvertebrate diversity and abundance were observed; this is represented by the seasonal variations in LIFE scores. Previous studies e.g. Joshi et al. (2007) on macroinvertebrate assemblage in the Himalayas region also observed maximum macroinvertebrate densities during winter and lower densities during the monsoon. Overall, LIFE scores were generally high (7.7-9.3) during the winter and summer seasons and low (minimum of 4.5) during the monsoon period. See Supplement 2 for the LIFE scores per site. The lower diversities and LIFE scores could be the result of the high monsoon flows washing the macroinvertebrates away.

Macroinvertebrate community structure changes across the seasons. High LIFE scores (winter and summer seasons) indicate an abundance of macroinvertebrates with a preference for high flows; this represents a high potential for instream supporting ecosystem services delivery. During the monsoon season, changes in the flow impacts on the macroinvertebrate structure resulting in low LIFE scores. Although macroinvertebrate response to these seasonal changes in river flows could be a natural process, human induced changes in the flow regime could negatively impact on the macro invertebrate community structure and the potential for supporting ecosystem services delivery.

\subsection{Influence of river flow changes on LIFE and supporting ecosystem services}

The observed seasonal variation in LIFE scores suggests that the macroinvertebrate community is responding to changes in river flow. This reflects the importance of the flow regime in the ecological health of rivers and their capacity to deliver ecosystem services (Vörösmarty et al., 2010). This implies that the observed decrease in temporal and seasonal river flows in the study basin could have a detrimental impact on macroinvertebrates and, consequently, the instream supporting ecosystem services. However, a greater understanding of the hydroecological relationship in the Beas River is required. To this end, the next steps in this study focus on hydroecological modelling, where numerical models are developed to explore the relationship.

Due to data limitations, long-term historic understanding of the macroinvertebrate community and LIFE in the basin are limited. Consequently, this narrows the scope within which the changes in LIFE scores could be assessed. Generally, research on macroinvertebrates in river systems in India has been limited (Mishra et al., 2013). Despite this, the successful application of the LIFE methodology and subsequent findings, helps to confirm the applicability of the methodology in snow fed river systems in India. Additionally, this 

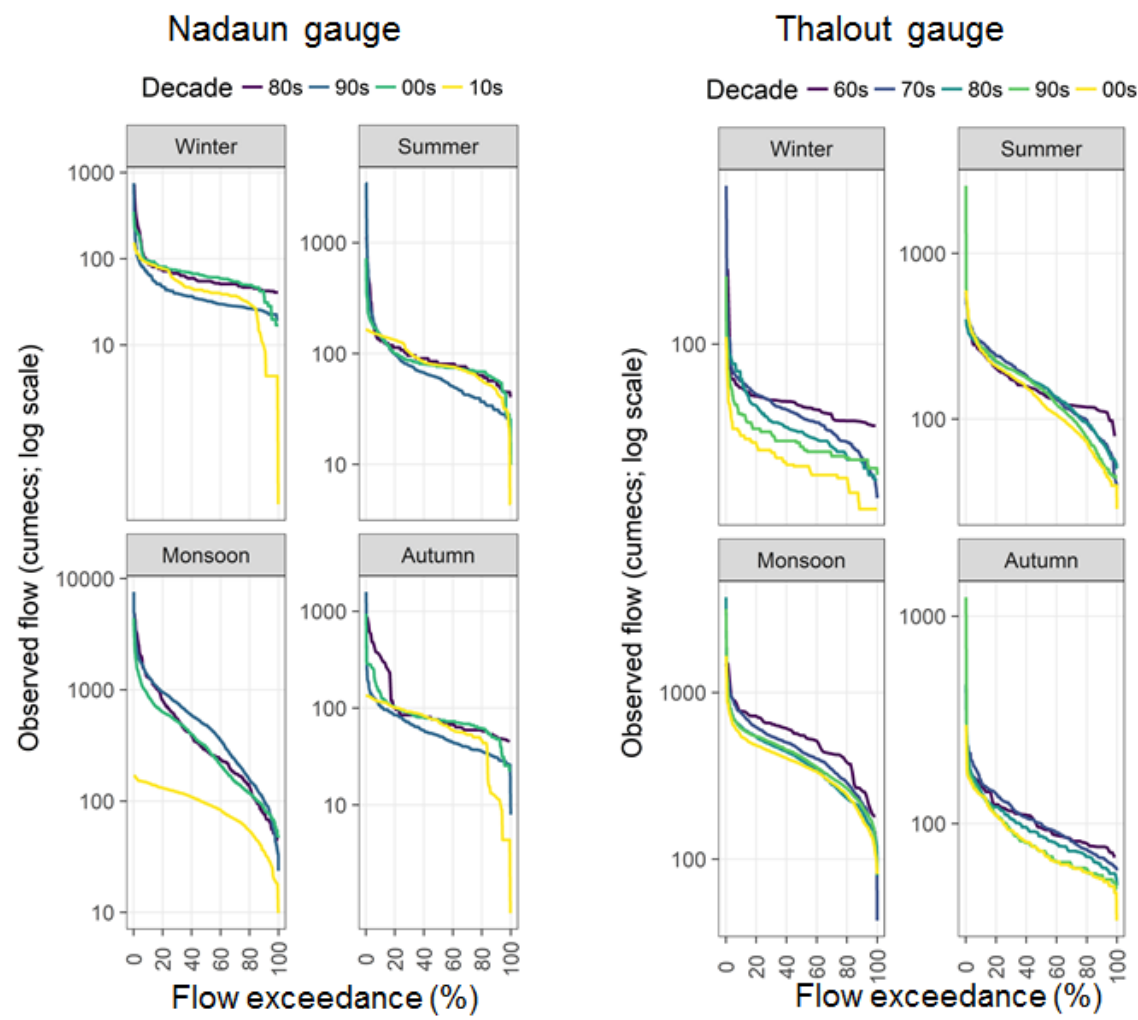

Figure 4. Flow distribution curves (by season and decade) at the two gauging stations.

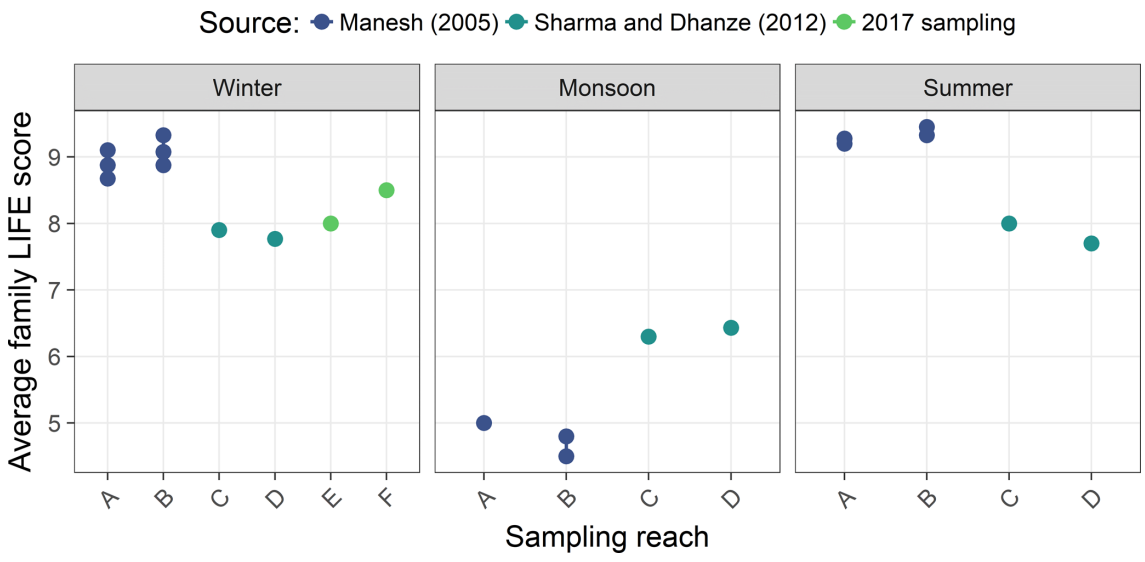

Figure 5. Seasonal variations in LIFE score.

study highlights the need for further work in the form of hydroecological modelling.

\section{Conclusions}

As part of an ongoing study, current findings presented in this paper, show that both mean monthly and seasonal cumulative flows have decreased overtime in the Beas Basin. Linked to this were seasonal variations in LIFE scores, indicative of macroinvertebrate response to flow changes and their potential to deliver supporting ecosystem services. However, further analysis is required to understand these hydroecological interactions and their impact on instream supporting ecosystem services. Given that more hydropower dams and abstraction activities and changing climatic conditions are set to continue, such an understanding is important in future water resources management planning in the Beas River Basin. 
Data availability. All macroinvertebrate data is provided in Manesh (2005), Sharma and Dhanze (2012) and in the Supplement of this article. All hydrological data is not publicly accessible and is provided for use in the project only from the Bhakra-Beas Management Board.

Supplement. The supplement related to this article is available online at: https://doi.org/10.5194/piahs-379-67-2018-supplement.

Competing interests. The authors declare that they have no conflict of interest.

Special issue statement. This article is part of the special issue "Innovative water resources management - understanding and balancing interactions between humankind and nature". It is a result of the 8th International Water Resources Management Conference of ICWRS, Beijing, China, 13-15 June 2018.

Acknowledgements. This work is part of an ongoing Sustaining Himalayan Water Resources in a changing climate (SusHi-Wat) research project and we acknowledge funding support from the UK Natural Environment Research Council (NERC; Project NE/N016394/1) and the Indian Ministry of Earth Sciences (MoES) under the aegis of the Newton-Bhabha scheme. We are also grateful to our project partners i.e. IITRoorkee, NIT-Hamirpur, NIH-Roorkee and IISc-Bangalore, Cranfield University, the British Antarctic Survey and the Bhakra-Beas Management Board.

Edited by: Zongxue Xu

Reviewed by: two anonymous referees

\section{References}

Barbour, M. T., Gerritsen, J., Snyder, B. D., and Stribling, J. B.: Rapid Bioassessment Protocols for Use in Streams and Wadeable Rivers: Periphyton, Benthic Macroinvertebrates and Fish, 2nd Edn., Environmental Protection Agency, Washington, DC, 1999.

Chaube, U. C., Sharma, S., Sharma, P., and Kumar, P.: Water quality assessment of River Satluj using benthic macroinvertebrates, in: Proceedings of the Scientific Conference on Rivers in the Hindu Kush-Himalaya - Ecology and Environmental Assessment, Nepal, 3-7 March 2008, 77-83, 2008.

Chauhan, A. and Verma, S. C.: Distribution and Diversity of Aquatic Insects in Himachal Pradesh, India: A Review, Int. J. Curr. Microbiol. Appl. Sci., 5, 273-281, 2016.

Extence, C. A., Balbi, D. M., and Chadd, R. P.: River flow indexing using British benthic macroinvertebrates: a framework for setting hydroecological objectives, Regul. Rivers, 15, 545-574, 1999.
Ghosh, D. and Biswas, J.: Macroinvertebrate diversity indices: A quantitative bioassessment of ecological health status of an oxbow lake in Eastern India, J. Adv. Environ. Health Res., 3, 7890, 2015.

Gilvear, D., Beevers, L., O'keeffe, J., and Acreman, M.: Environmental Water regimes and natural capital - Free Flowing Ecosystem Services, in: Water for the Environment: From Policy and Science to Implementation and Management, 1st Edn., edited by: Horne, A., Webb, A., Stewardson, M., Richter, B., and Acreman, M., Academic Press, Elsevier, 151-173, 2017.

Jain, S. K., Goswami, A., and Saraf, A. K.: Assessment of Snowmelt Runoff Using Remote Sensing and Effect of Climate Change on Runoff, Water Resour. Manag., 24, 1763-1777, 2010.

Joshi, P. C., Negi, R. K., and Negi, T.: Seasonal variation in benthic macro-invertebrates and their correlation with environmental variables in fresh water stream in Garhwal region (India), Life Sci., 4, 227-234, 2007.

Manesh, K.: Ecology of some selected hillstreams of the river Beas in the vicinity of the upper Himalayas of Himachal Pradesh, PhD thesis, Department of Zoology, Panjab University, India, http:// hdl.handle.net/10603/82916 (last access: 25 April 2018), 2005.

Millennium Ecosystem Assessment: Ecosystems and Human Wellbeing: Synthesis, Washington, DC, 2005.

Mishra, A. S., Nautiyal, P., and Semwal, V. P.: Distributional Patterns of Benthic Macro-Invertebrate Fauna in the Glacier Fed Rivers of Indian Himalaya, Our Nature, 11, 36-44, 2013.

Monk, W. A., Wood, P. J., Hannah, D. M., Wilson, D. A., Extence, C. A., and Chadd, R. P.: Flow variability and macroinvertebrate community response within riverine systems, River Res. Appl., 22, 595-615, 2006.

Monk, W. A., Wood, P. J., Hannah, D. M., and Wilson, D. A.: Macroinvertebrate community response to inter-annual and regional river flow regime dynamics, River Res. Appl., 24, 988 1001, 2008.

Sharma, I. and Dhanze, R.: Evaluation of macrobenthic fauna in hill stream environment of Western Himalaya, India, JoTT, 4, 2875-2882, http://threatenedtaxa.org/index.php/JoTT/article/ view/790/1415 (last access: 25 April 2018), 2012.

Singhvi, A. K. and Krishnan, R.: Past and the Present Climate of India, in: Landscapes and Landforms of India, edited by: Kale, V. S., Dordrecht, 2014.

Subramanian, K. A. and Sivaramakrishnan, K. G.: Aquatic Insects of India-A Field Guide, Ashoka Trust for Ecology and Environment (ATREE), Bangalore, India, 2007.

Thorp, J. H., Flotemersch, J. E., Delong, M. D., Casper, A. F., Thoms, M. C., Ballantyne, F., Williams, B. S., O’Neill, B. J., and Haase, C. S.: Linking Ecosystem Services, Rehabilitation, and River Hydrogeomorphology, BioScience, 60, 67-74, 2010.

Vörösmarty, C. J., McIntyre, P. B., Gessner, M. O., Dudgeon, D., Prusevich, A., Green, P., Glidden, S., Bunn, S. E., Sullivan, C. A., Liermann, C. R., and Davies, P. M.: Global threats to human water security and river biodiversity, Nature, 467, 555-561, 2010.

Wallace, J. B. and Webster, J. R.: The Role Of Macroinvertebrates In Stream Ecosystem Function, Annu. Rev. Entomol., 41, 115139, 1996. 